\title{
Effects of exogenous phytase in chickens fed diets with differently processed rapeseed expeller cakes ${ }^{*}$
}

\author{
S. Smulikowska ${ }^{1}$, A. Mieczkowska, J. Czerwiński, D. Weremko \\ and C.V. Nguyen
}

The Kielanowski Institute of Animal Physiology and Nutrition, Polish Academy of Sciences 05-110 Jabłonna, Poland

(Received 7 November 2005; revised version 15 February 2006; accepted 12 April 2005)

\begin{abstract}
The effects of phytase supplementation on the nutritional value, $\mathrm{P}$ availability and thyroid status of birds fed 4 differently processed rapeseed expeller cakes (RC) were determined. Two experiments were performed: a balance experiment on 10 groups of nine 3-week-old broilers and a growth experiment on 9 groups of one-day-old broiler females, 11 birds per group. In the balance experiment, a basal (B) and 4 test diets (B mixed with $\mathrm{RC}$ in a 6:4 proportion with $\mathrm{DM}$ ) were fed; half of each diet was supplemented with $1000 \mathrm{U}$ phytase $/ \mathrm{kg}$. In the growth experiment, the control diet without $\mathrm{RC}$ and isonitrogenous diets with RC supplemented or unsupplemented with $1000 \mathrm{U}$ phytase $/ \mathrm{kg}$ (RCP) were fed. The amount of RC was 100 or $150 \mathrm{~g} / \mathrm{kg}$ in diets fed between days $1-21$ and 22-42 of life, respectively. The levels of $\mathrm{Ca}$ and available $\mathrm{P}$ in $\mathrm{RC}$ diets were as in the control diet, while in RCP diets they were lowered by 7 and $12 \%$, respectively.

Phytase supplementation increased apparent protein digestibility and metabolizable energy values, while it did not affect $\mathrm{P}$ availability from RC. BWG was lower in some groups and FCR $5 \%$ worse $(\mathrm{P}<0.05)$ in all $\mathrm{RC}$ groups than in the control. The type of RC significantly affected feed intake, BWG, thyroid and kidney weight. Addition of phytase to RCP diets increased thyroid weight $(\mathrm{P}<0.01)$. Phytase addition did not fully compensate for lower $\mathrm{Ca}$ and $\mathrm{P}$ levels in RCP diets, as tibia ash content was reduced $(\mathrm{P}<0.05)$, but this had no effect on tibia weight and ultimate strength.
\end{abstract}

KEY WORDS: rapeseed cake, phytase, P availability, broiler chickens, performance, thyroids

\footnotetext{
* Preliminary results were presented at the 26th Conference on Oilseed Crops, Poznań (Poland), 2004 and at the 15th European Symposium on Poultry Nutrition, Balatonfüred (Hungary), 2005

${ }^{1}$ Corresponding author: e-mail: s.smulikowska@ifzz.pan.pl
} 


\section{INTRODUCTION}

Rapeseed expeller cake (RC) is a relatively new commercial product, which remains after de-oiling 00 rape seeds by pressing. Its market share is growing, as expelling technology is more cost-effective and environmentally friendly than prepressig/solvent extraction, yielding rapeseed meal as the final product. The nutritional value of RC is not standardized yet and depends on the chemical composition of the seeds, which is affected by genetic and environmental factors, and on nutrient digestibility and glucosinolate toxicity, which are affected mainly by processing conditions. In Poland, rapeseed is processed on different types of screw press expellers, and the expelling technology may be accompanied by extrusion or hydrothermal treatment called toasting. Both treatments may affect myrosinase (thioglucoside glucohydrolase EC 3.2.3.1) activity, which, under suitable conditions in the gastrointestinal tract, hydrolyzes glucosinolates to thyrotoxic compounds. A sensitive indicator of the dietary glucosinolate level and myrosinase status in pigs and chickens is the weight of the thyroid, liver and kidneys (Schöne et al., 1991, 1997; Bell, 1993).

Rape seeds are rich in phosphorus, which is present mainly in the form of phytates - phytic acid salts (myo-inositol hexakisdihydrogenphosphate-IP ${ }_{6}$ ), which are not fully available to chickens and may have a negative effect on the availability of minerals and on protein digestion. Various phytate-degrading enzyme preparations have been tested on rapeseed meal in vitro. Their efficiency depends on enzyme composition and activity, pH and time of incubation. Żyła and Koreleski (1993) found complete dephosphorylation in $4 \mathrm{~h}$ incubation with $100 \mathrm{U}$ phytase and 37100 $\mathrm{U}$ acid phosphatase $/ \mathrm{kg}$ at $\mathrm{pH} 4.5$. Rutherfurd et al. (2004) showed that during $4 \mathrm{~h}$ incubation with 500 to 2000 phytase $\mathrm{U} / \mathrm{kg}$ at pH 5.5, from 28 to $54 \%$ phytate $\mathrm{P}$ was released, while Newkirk and Classen (1998) reported that complete hydrolysis

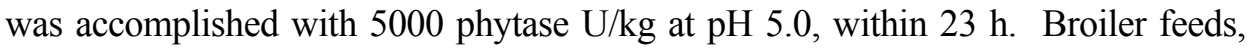
containing wheat as a major component, are commonly supplemented with xylanases. The efficacy of phytase in wheat-based broiler diets can be enhanced by adding xylanase to feeds (Żyła et al., 1999). There is little information about the effect of rapeseed products, which are rich in condensed tannins, on the efficacy of exogenous phytase in the presence of xylanase in the digestive tract of chickens. In vivo, Żyła and Koreleski (1993) found a positive effect of phytase derived from Aspergillus niger on rapeseed meal phytate phosphorus utilization in broilers, while Rutherfurd et al. (2002) reported no statistically significant effect of added phytase on ileal total and phytate $\mathrm{P}$ digestibility in broilers fed a rapeseed meal-based diet.

The aim of the study was to evaluate the effect of phytase supplementation on the digestibility of nutrients from differently processed rapeseed cakes, and on performance, thyroid status and skeletal development in broilers fed diets containing RC. 


\section{MATERIAL AND METHODS}

\section{Materials}

Four rapeseed press cakes (RC), produced from 00 rapeseed (unknown cultivars, harvest year 2002) in 4 different small rural mills were used (Tables 1, 2 and 3). The following processing conditions were applied: RC 1 - seeds were flaked, steam conditioned for $90 \mathrm{~min}$ at temperatures increasing from 60 to $105^{\circ} \mathrm{C}$, pressed on a De Smet-Rosedowens screw expeller and pelleted $(10 \times 10 \mathrm{~mm})$; RC 2 - seeds were pressed on a CB-50 screw press expeller (Germany) and pelleted $(20 \times 5 \mathrm{~mm})$; RC 3 - seeds were heated to $60^{\circ} \mathrm{C}$, flaked and pressed on a $02 \mathrm{PVO}$ screw press expeller (Bispomasz, Bydgoszcz, Poland); RC 4 - seeds were heated to $50^{\circ} \mathrm{C}$, pressed on a $02 \mathrm{PVO}$ screw press expeller, dry extruded $\left(125-150^{\circ} \mathrm{C}\right.$

Table 1. Chemical composition of rapeseed expeller cakes (RC), in $\mathrm{g} / \mathrm{kg} \mathrm{DM}$ and the total amino acid and available lysine contents $(\mathrm{g} / 16 \mathrm{~g} \mathrm{~N})$

\begin{tabular}{|c|c|c|c|c|}
\hline Component & $\mathrm{RC} 1$ & RC 2 & RC 3 & $\mathrm{RC} 4$ \\
\hline $\mathrm{DM}, \mathrm{g} / \mathrm{kg}$ & 911 & 909 & 911 & 893 \\
\hline Crude protein & 331 & 297 & 272 & 337 \\
\hline Crude fat ${ }^{1}$ & 136 & 169 & 222 & 111 \\
\hline Crude ash & 68 & 60 & 54 & 65 \\
\hline Crude fibre & 118 & 126 & 130 & 116 \\
\hline $\mathrm{N}$-free extractives & 347 & 348 & 322 & 371 \\
\hline Acid detergent fibre (ADF) & 203 & 190 & 205 & 200 \\
\hline Neutral detergent fibre (NDF) & 293 & 229 & 244 & 241 \\
\hline NDIN (NDF-bound protein), $\%$ total & 16.3 & 8.5 & 9.3 & 7.4 \\
\hline Total P & 11.7 & 9.63 & 9.55 & 10.9 \\
\hline Phytate P & 5.6 & 4.1 & 4.8 & 4.0 \\
\hline \multicolumn{5}{|l|}{ Amino acids, $g / 16 g N$} \\
\hline lysine total & 6.15 & 6.15 & 6.25 & 5.94 \\
\hline lysine available & 5.19 & 5.10 & 5.18 & 5.53 \\
\hline methionine & 1.86 & 1.88 & 1.82 & 1.85 \\
\hline cystine & 2.22 & 2.23 & 2.20 & 2.21 \\
\hline threonine & 4.81 & 4.68 & 4.68 & 4.37 \\
\hline tryptophan & 1.24 & 1.27 & 1.22 & 1.25 \\
\hline arginine & 6.55 & 6.45 & 6.36 & 6.09 \\
\hline valine & 5.58 & 5.37 & 5.47 & 5.13 \\
\hline isoleucine & 4.43 & 4.28 & 4.40 & 4.11 \\
\hline leucine & 7.67 & 7.44 & 7.45 & 7.12 \\
\hline phenyloalanine & 4.37 & 4.25 & 4.21 & 4.07 \\
\hline tyrosine & 3.22 & 3.11 & 3.11 & 2.92 \\
\hline histidine & 2.87 & 2.76 & 2.74 & 2.66 \\
\hline
\end{tabular}

after acid hydrolysis 
Table 2. Lysine availability, $\left(\mathrm{Lys}_{\text {available }} / \mathrm{Lys}_{\text {total }} \times 100\right)$ and solubility of protein from rapeseed expeller cakes (RC)

\begin{tabular}{llllll}
\hline Item & RC 1 & RC 2 & RC 3 & RC 4 & SEM \\
\hline Lysine availability, \% & $84.4^{\mathrm{A}}$ & $82.9^{\mathrm{A}}$ & $82.9^{\mathrm{A}}$ & $93.1^{\mathrm{B}}$ & 0.72 \\
Protein solubility in 0.5\% KOH, \% & $59.8^{\mathrm{aA}}$ & $90.9^{\mathrm{cB}}$ & $88.3^{\mathrm{bB}}$ & $86.7^{\mathrm{bB}}$ & 0.61 \\
Protein solubility in borate, \% & $39.9^{\mathrm{A}}$ & $87.2^{\mathrm{C}}$ & $86.8^{\mathrm{C}}$ & $58.3^{\mathrm{B}}$ & 0.64 \\
Protein dispersibility index (PDI), \% & $12.5^{\mathrm{A}}$ & $24.8^{\mathrm{C}}$ & $24.2^{\mathrm{C}}$ & $17.7^{\mathrm{B}}$ & 0.22 \\
\hline
\end{tabular}

${ }_{\mathrm{a}, \mathrm{b}, \mathrm{A}, \mathrm{B}}$ means in rows with different superscripts statistically significant at ${ }^{\mathrm{ab}} \mathrm{P}<0.05 ;{ }^{\mathrm{AB}} \mathrm{P}<0.001$

Table 3. Glucosinolate content of rape seeds and rapeseed expeller cakes (RC), $\mu \mathrm{mol} / \mathrm{g}$ DM

\begin{tabular}{|c|c|c|c|c|c|c|c|c|}
\hline \multirow{2}{*}{ Glucosinolates } & \multicolumn{4}{|c|}{ Rape seeds } & \multicolumn{4}{|c|}{ Rapeseed expeller cakes } \\
\hline & 1 & 2 & 3 & 4 & $\mathrm{RC} 1$ & $\mathrm{RC} 2$ & RC 3 & $\mathrm{RC} 4$ \\
\hline \multicolumn{9}{|l|}{ Alkenyl-glucosinolates } \\
\hline progoitrin & 6.09 & 4.78 & 3.62 & 3.72 & 6.80 & 4.73 & 3.84 & 5.37 \\
\hline gluconapoleiferin & 0.32 & 0.33 & 0.21 & 0.33 & 0.11 & 0.44 & 0.33 & 0.34 \\
\hline gluconapin & 4.70 & 4.20 & 3.30 & 3.08 & 5.71 & 2.97 & 2.74 & 3.69 \\
\hline glucobrassicanapin & 1.28 & 1.04 & 0.85 & 0.53 & 1.43 & 0.88 & 0.77 & 0.90 \\
\hline$\Sigma$ alkenyl glucosinolates & 12.4 & 10.3 & 8.0 & 7.7 & 14.0 & 9.0 & 7.7 & 10.3 \\
\hline \multicolumn{9}{|l|}{ Indol-glucosinolates } \\
\hline 4-hydroxyglucobrassicin & 3.20 & 3.40 & 2.45 & 3.99 & 2.63 & 3.85 & 4.17 & 5.26 \\
\hline other indol glucosinolates & 0.11 & 0.16 & 0.11 & 0.21 & 0.11 & 0.11 & 0.11 & 0.22 \\
\hline Total glucosinolates (TGL) & 15.7 & 13.9 & 10.5 & 11.9 & 16.8 & 13.0 & 12.0 & 15.8 \\
\hline TGL, $\mu \mathrm{mol} / \mathrm{g}$ FFDM & 28.4 & 24.8 & 19.2 & 21.2 & 19.4 & 17.2 & 15.4 & 18.0 \\
\hline $\begin{array}{l}\text { TGL in FFDM, } \\
\text { relative to seeds, } \%\end{array}$ & 100 & 100 & 100 & 100 & 68 & 70 & 80 & 85 \\
\hline
\end{tabular}

FFDM - fat-free DM

for $20 \mathrm{sec}$ ) and pressed again. The RCs were ground to a fine texture prior to incorporation into diets.

Two commercial enzyme preparations were used: Avizyme 1300 (Finnfeeds Int.), which contained xylanase and $\beta$-glucanase activity, and Natuphos 5000 G (BASF), which contained 5000 FTU phytase/g, according to the producer's declaration. Actual phytase activity in the feed samples was not measured.

\section{Diets}

In Experiment 1 (digestibility trial) 2 basal diets (B and BP) were prepared. The $\mathrm{B}$ diet contained $(\mathrm{g} / \mathrm{kg})$ : wheat 454.3 , maize 200, soyabean meal 280.7, limestone 14, dicalcium phosphate $10, \mathrm{NaCl} 3$, rapeseed oil 30, L-lysine (78\%) 1, DL-methionine (0.98\%) 1, Avizyme 13001 and mineral-vitamin premix 5. The BP diet of the same composition was supplemented with $1000 \mathrm{U}$ phytase per $\mathrm{kg}$ 
DM. Eight test diets (T) were composed of the B diet mixed with different RC in a proportion of $6: 4$ on a DM basis. Diets denoted as RC were unsupplemented, while the RCP diets were supplemented with $1000 \mathrm{U}$ phytase per $\mathrm{kg}$. The total $\mathrm{P}$ level in the basal diets (B and BP) was 6.4, in the test diets, from 7.6 to $8.1 \mathrm{~g} / \mathrm{kg}$ air-dry matter. All diets contained $3 \mathrm{~g} \mathrm{Cr}_{2} \mathrm{O}_{3}$ per $\mathrm{kg} \mathrm{DM}$ as a marker and were cold pelleted on a CL-2 CPM Laboratory Pellet Mill.

In Experiment 2 (growth trial), two sets of diets were prepared (Tables 4 and 5), with nutrient contents covering chicken requirements during the starter (121 ), grower (22-35) and finisher (36-42 d of life) periods. The control diet did not contain RC, while the experimental diets contained 100 (starters) or $150 \mathrm{~g} / \mathrm{kg}$ respective RC (growers and finishers). Diets denoted as RC were unsupplemented and had $\mathrm{P}$ and $\mathrm{Ca}$ contents equal to the control diet, while diets denoted as RCP contained $18 \%$ less inorganic $\mathrm{Ca}$ and $\mathrm{P}$ due to a lower amount of added dicalcium phosphate than the respective RC diets and were supplemented with $1000 \mathrm{U}$ phytase $/ \mathrm{kg}$. All diets were cold pelleted.

\section{Animal trials}

In the digestibility trial, 90 three-week-old broiler females with a mean initial body weight of $677 \mathrm{~g}$ were used. The birds, housed individually in balance cages, were allocated to 10 groups, 9 birds per group, and were given $90 \mathrm{~g} / \mathrm{bird} /$ day of the respective balance diets, in three meals. After two days of preliminary feeding the birds were fasted for $14 \mathrm{~h}$, then given the same diets for 3 days and again fasted for $14 \mathrm{~h}$. Feed intake was recorded daily, while during the last $86 \mathrm{~h}$ of the experiment, excreta were quantitatively collected, frozen and kept at $-18^{\circ} \mathrm{C}$ for further analysis.

In the growth trial, 99 one-day-old Cobb 500 broiler females with a mean initial body weight of $43.4 \mathrm{~g}$ were randomly allocated into 9 groups, 11 birds per group. For the first week the chickens were kept in pens, on day 8 they were weighed and placed into individual cages. From the first day of life the birds were given the experimental diets ad libitum: for weeks 1 to 3, starters (Table 4), for weeks 3 to 6, growers, for week 7 finishers (Table 5). Body weight and feed intake were measured in weekly intervals after $4 \mathrm{~h}$ feed deprivation. At the end of the experiment the birds were killed by cervical dislocation, the abdominal cavity was opened and the liver, thyroid glands, kidneys and abdominal fat were excised and weighed. The right tibias were collected, cleaned of all exterior tissue and frozen until analysis.

Both experiments were conducted in compliance with the European Union regulations concerning the protection of experimental animals. The Local Ethics Committee approved the study protocol. 


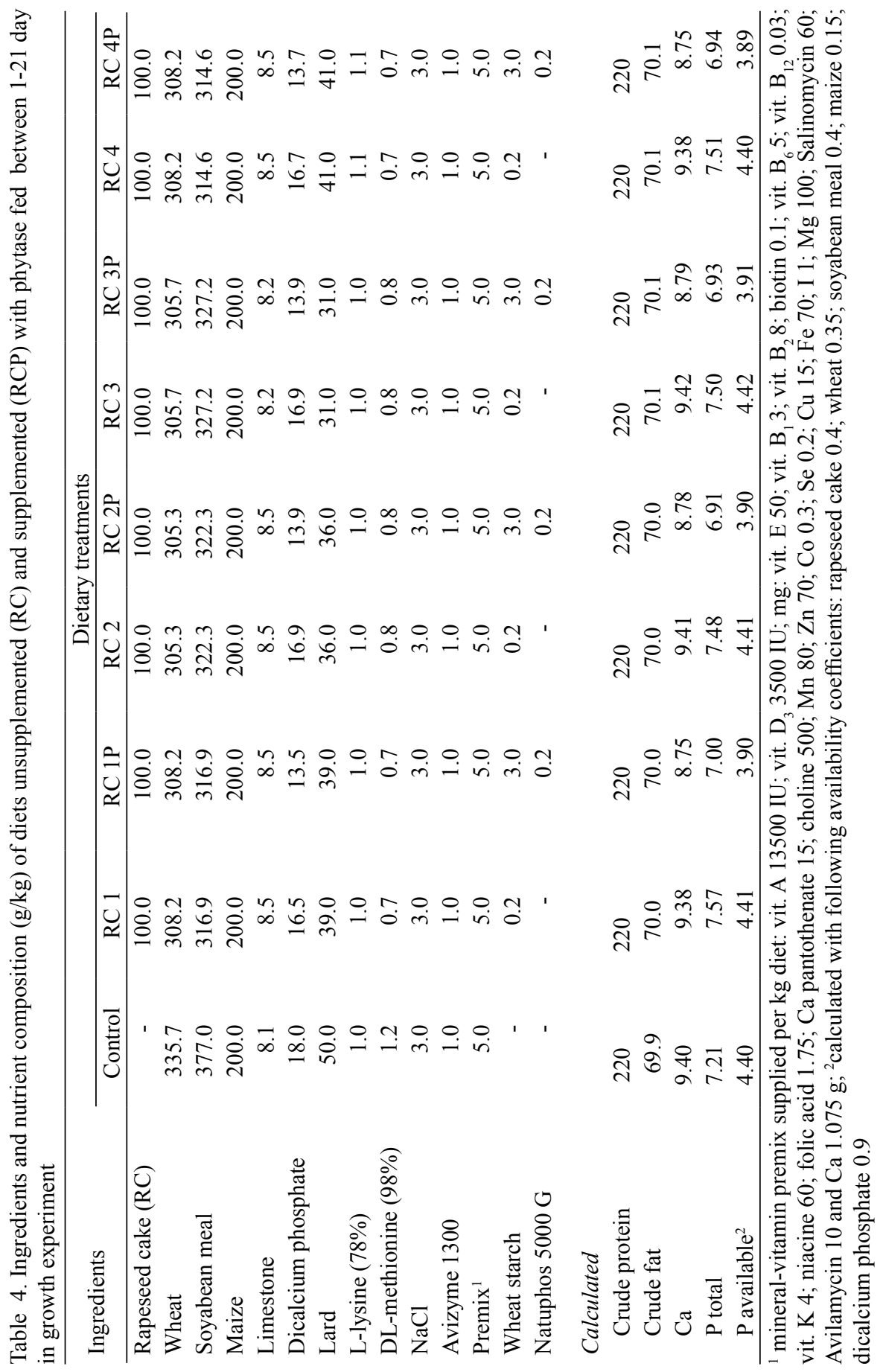




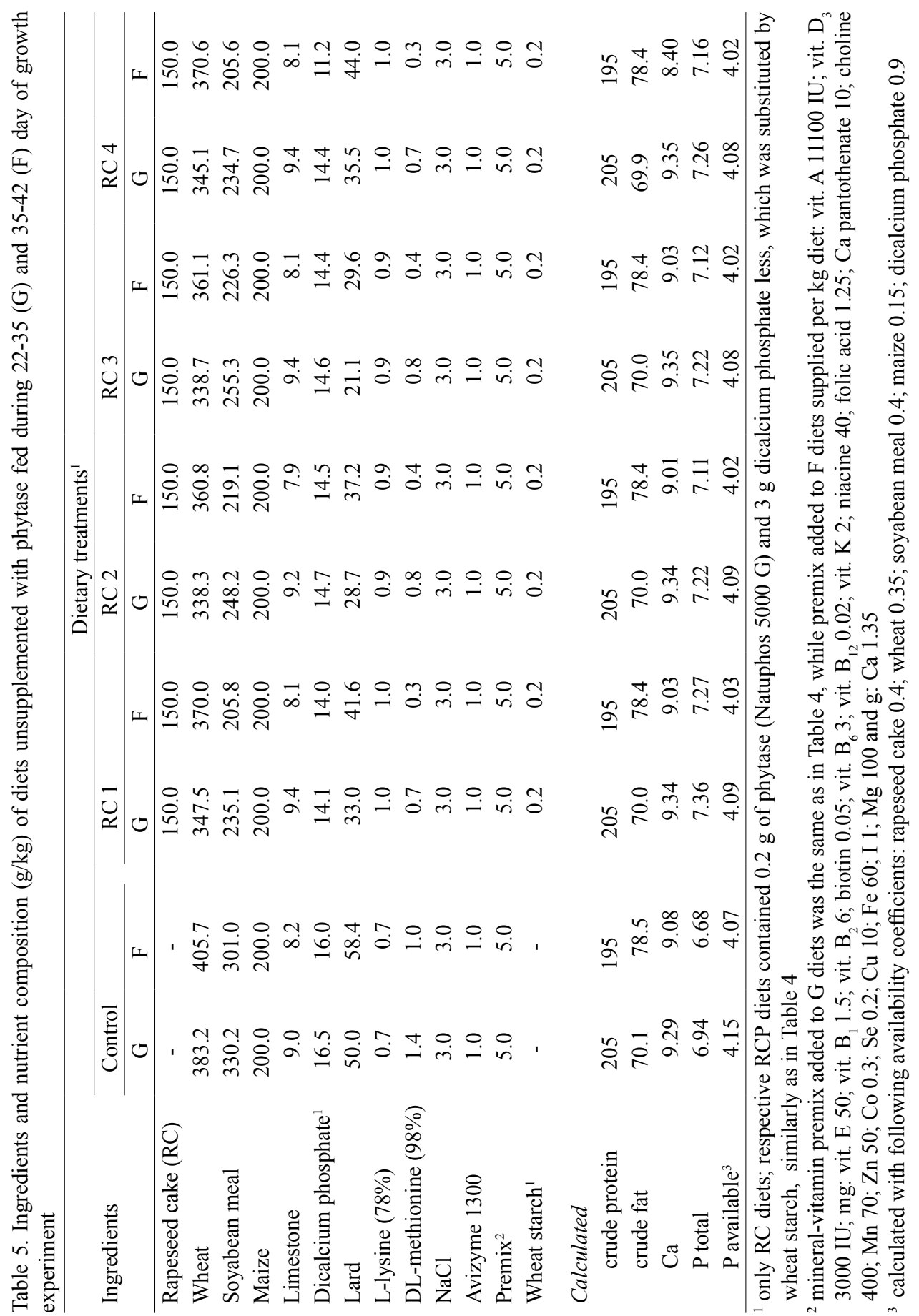




\section{Measurements of protein solubility in rapeseed cakes}

Solubility in $0.5 \% \mathrm{KOH}$ was determined as described by Pastuszewska et al. (1998); solubility in sodium borate was determined according to Lee and Garlich (1992). The protein dispersibility index (PDI), that measures protein solubility in water during mechanical blending at $8500 \mathrm{RPM}$ for $10 \mathrm{~min}$, was determined according to Dudley-Cash (1999).

\section{Measurements of tibia strength and tibia ash content}

Tibias were weighed and analysed for strength by shear force measurement using a Texture Analyser TA-XT2i (Stable Micro Systems). After the shear test, the tibias were dried, crushed and defatted in refluxing ethyl ether in a Soxlet apparatus for $48 \mathrm{~h}$. The defatted tibias were oven dried and ashed in ceramic crucibles for $24 \mathrm{~h}$ at $600^{\circ} \mathrm{C}$. Ash content was expressed as a percentage of the fat-free, moisture-free tibia weight.

\section{Chemical analysis}

Prior to analysis the excreta were dried for $12 \mathrm{~h}$ at $60^{\circ} \mathrm{C}$, kept open for $48 \mathrm{~h}$ and ground to pass a $1 \mathrm{~mm}$ sieve. The chemical composition of press cakes, diets and excreta was determined according to AOAC (1990), (code no. 930.04; 978.04; 930.05; 930.10; 958.01 for dry matter, crude protein, ash, crude fibre and P total, respectively). Crude fat was determined by ether extraction preceded by acidification with $4 \mathrm{M}$ hydrochloric acid. In rapeseed cakes, glucosinolates were determined according to the ISO 9167-1 method (1992), using a HPLC 1050 apparatus, phytate $\mathrm{P}$ was measured according to Tangkongchitr et al. (1981), neutral detergent fibre (NDF), acid detergent fibre (ADF) and NDF insoluble nitrogen (NDIN) were determined with a Fibertec System M according to Van Soest and Wine (1967) and Van Soest (1973). Amino acid analyses were performed with a Beckman 6300 high pressure amino acid analyser, using modified procedures described by Buraczewska and Buraczewski (1984), available lysine was analysed according to the Carpenter method modified by Booth (1971). Faecal N was determined according to Ekman et al. (1949). Gross energy of RC, diets and excreta were measured on a Parr adiabatic oxygen bomb calorimeter KL-10, chromic oxide was determined spectrophotometrically following wet ashing according to Hinsberg et al. (1953).

\section{Calculations and statistics}

In Experiment 1 the total tract apparent digestibility (CTTAD) of dietary protein, fat, organic matter and phosphorus retention and apparent metabolizable energy 
$\left(A M E_{N}\right)$ value of diets were calculated relative to the ratio of $\mathrm{Cr}_{2} \mathrm{O}_{3}$ to the content of the nutrient in question or gross energy in feed and excreta. $\mathrm{AME}_{\mathrm{N}}$ was corrected to zero nitrogen balance using $34.96 \mathrm{~kJ} / \mathrm{g} \mathrm{N}$ retained (Hill and Anderson, 1958). Respective values for rapeseed cakes were calculated by assuming additivity of the values of the basal (B) and the test $(T)$ diets, from the formula: $A M E_{N} R C=A M E_{N}$ $\mathrm{B}-(1-\mathrm{X}) \mathrm{AME}_{\mathrm{N}} \mathrm{T} / \mathrm{X}$, where $\mathrm{X}=$ the level of inclusion of $\mathrm{RC}$ in the $\mathrm{T}$ diet. The values obtained for the $\mathrm{B}$ diet were used for calculation of respective values for phytase unsupplemented $\mathrm{RC}$, while the values obtained for the BP diet for phytase supplemented RC. In experiment 2 the body weight gain (BWG) and feed conversion ratio (FCR) were calculated for 42 days of feeding, the weights of thyroids, livers and kidneys were calculated relative to live body weight before slaughter.

The results were subjected to one-way and two-way analysis of variance (ANOVA) generated by Statgraphics ${ }^{\circledR}$ ver. 5.1 software (SAS, 1994-2001).

\section{RESULTS}

Press cakes contained from 111 to $222 \mathrm{~g}$ crude fat $/ \mathrm{kg}$, from 272 to $337 \mathrm{~g}$ crude protein $/ \mathrm{kg}$ and from 9.55 to 11.7 total $\mathrm{P} / \mathrm{kg}$, of which from 37 to $50 \%$ was phytate P. The amino acid composition of RC protein was rather uniform, total lysine ranged from 5.94 to $6.25 \mathrm{~g} / 16 \mathrm{~g} \mathrm{~N}$, in it from 83 to $93 \%$ was available lysine (Tables 1 and 2). The share of ADF in fat-free dry matter (FFDM) was about 23\% in all RC, while NDF was less uniform and was highest (29\%) in RC 1, it was associated with a substantially higher value of NDIN than in the remaining RC (Table 1). The protein solubility and dispersibility indexes were lower in RC 1 and RC 4, higher in RC 2 and RC 3 (Table 2). The glucosinolate concentrations were from 19 to $28 \mu \mathrm{mol} / \mathrm{g}$ FFDM in rape seeds, and from 15 to $19 \mu \mathrm{mol} / \mathrm{g}$ FFDM in RC (Table 3).

The results of the balance trial (Table 6) showed that the CTTAD of protein was from $75.4 \%$ for RC 1 to $78.9 \%$ for RC 4 and significantly increased after phytase supplementation in RC 1 and RC 3, while CTTAD of fat was lowest in RC 4, highest in RC 1, and decreased after phytase supplementation in RC 1 and RC 2. Organic matter retention in RC 1 amounted to $36.6 \%$, while in the remaining $\mathrm{RC}$ it averaged $46.4 \%$. After phytase supplementation it increased in RC 1 by 6 percentage points, while in the remaining RCs it increased by only 0.7 percentage points.

The $\mathrm{AME}_{\mathrm{N}}$ value was the lowest in RC 1, the highest in RC 3, and depended significantly $(\mathrm{P}<0.05)$ on the fat content in $\mathrm{RC}$ according to the equation:

$\mathrm{AME}_{\mathrm{N}}(\mathrm{MJ} / \mathrm{kg} \mathrm{DM})=7.58+0.03 \times$ total fat content in $\mathrm{g} / \mathrm{kg} \mathrm{DM}(\mathrm{r}=0.93)$.

Phytase supplementation increased the $\mathrm{AME}_{\mathrm{N}}$ value of $\mathrm{RC} 1$ by $11 \%$, but did not significantly affect the $\mathrm{AME}_{\mathrm{N}}$ value of the remaining cakes (Table 6). 


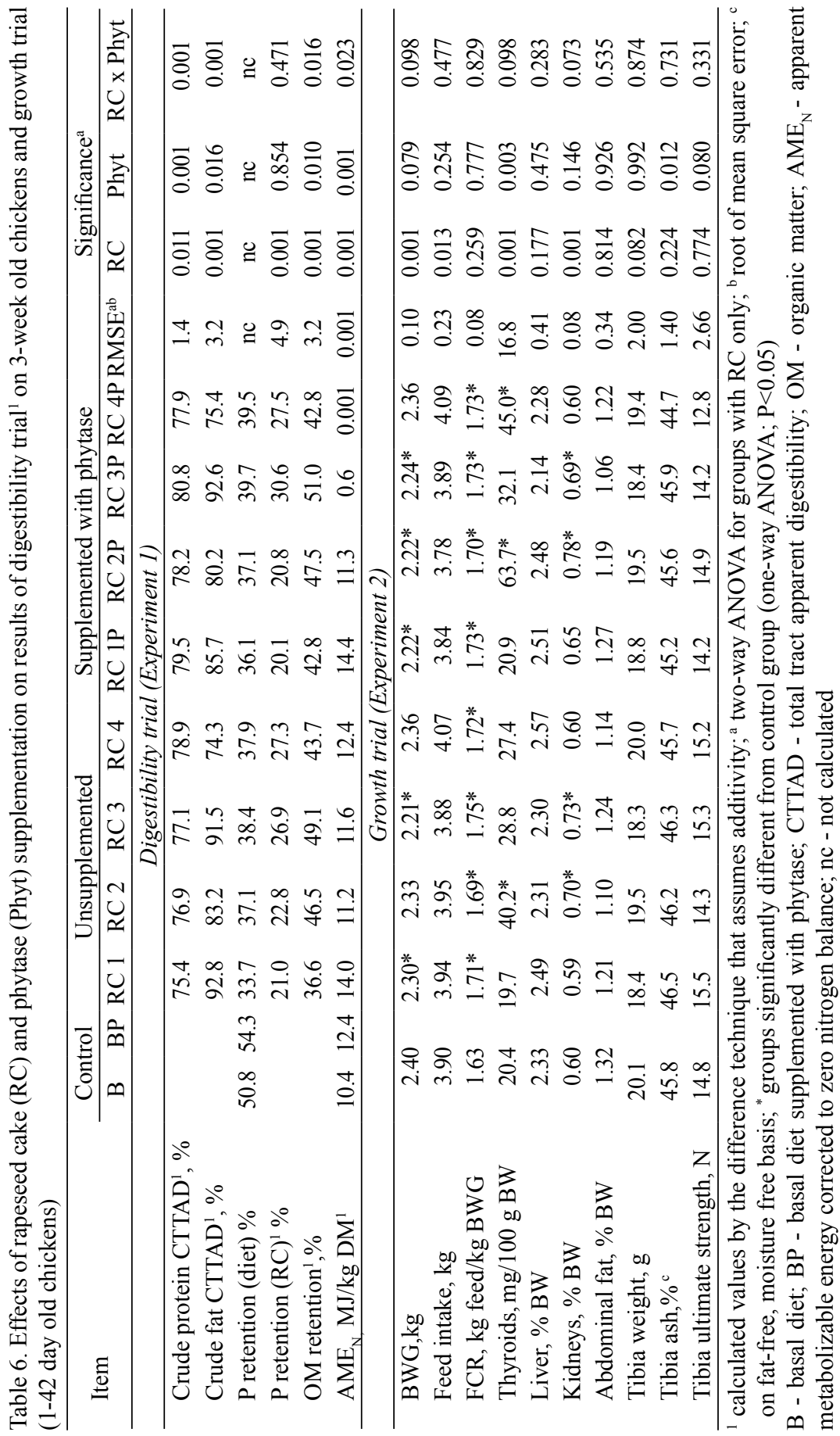


Phosphorus retention from the BP diet was 3.5 percentage points higher than from diet B, while from unsupplemented test diets containing $40 \% \mathrm{RC}$ it averaged $36.8 \%$, from phytase-supplemented test diets it averaged $38.1 \%$. Phosphorus retention calculated by a difference technique that assumes additivity was from $21 \%$ in RC 1 to $27.3 \%$ in RC 4 and did not increase significantly after phytase supplementation. There was no significant interaction between effect of type of RC and phytase supplementation on P retention (Table 6).

During the 42-day growth trial, feed intake in RC groups did not differ from that in the control group (Table 6), but BWG was significantly lower in groups $\mathrm{RC} 1$ and $\mathrm{RC} 3$. This resulted on average in a 5\% worse FCR in all RC groups compared with the control. Type of RC significantly affected feed intake $(\mathrm{P}<0.05)$ and $\mathrm{BWG}(\mathrm{P}<0.001)$, as it was higher in group $\mathrm{RC} 4$ than in the remaining ones, however, neither the type of RC nor phytase supplementation affected FCR significantly (Table 6).

The type of RC and phytase supplementation had no effect on liver and abdominal fat weight, while the kidneys were enlarged $(\mathrm{P}<0.05)$ in groups fed RC 2 and RC 3, the thyroids were enlarged significantly in group RC 2, and numerically in groups RC 3 and RC 4 compared with the control group. Phytase supplementation significantly increased the weight of thyroids in chickens fed RC 2 and RC 4 cakes compared with unsupplemented ones (Table 6). In the growth trial there were no interactions among any measured parameters between the type of rapeseed cake and phytase supplementation.

The tibia weight, tibia ash and tibia ultimate strength in chickens fed RC diets did not differ compared with the control group. In groups fed RC diets with a lower $\mathrm{Ca}$ and $\mathrm{P}$ content and supplemented with phytase, the tibia ash content was reduced on average by $2 \%(\mathrm{P}<0.05)$ in comparison with the respective unsupplemented groups, but tibia weight and its ultimate strength were not affected (Table 6).

\section{DISCUSSION}

In two batches of the commercial grade rape seeds used in this study the glucosinolate content was below the upper limit, in one batch, at the upper limit

and in one, above the upper limit of $25 \mathrm{mmol} / \mathrm{kg}$ FFDM defining 00 rapeseed quality, that was proposed some time ago (Krzymański, 1993). In RC, the glucosinolate content ranged from 15 to $19 \mathrm{mmol} / \mathrm{kg}$ FFDM. The differences in RC composition in this report reflect the various combinations of differences in the composition of the seeds that were processed and differences in processing factors. It was not the objective of this study to explain the reasons for differences in RC composition 
attributed to cultivar or environmental factors, but rather to assess the variation connected with processing conditions. The range of fat and protein content in $\mathrm{RC}$ used in the present study was similar, while glucosinolate content was lower than reported previously (Smulikowska et al., 1997). Differences in glucosinolate content reflect cultivar, environmental and processing factors, while processing strongly affected fat content. Extrusion, which was part of the production process for RC 4, enabled the most effective oil extraction. Reduction of protein dispersibility in water (PDI) and its solubility in borate and $0.5 \% \mathrm{KOH}$, as well as a substantially higher proportion of NDIN were observed in RC 1 toasted for 90 min at temperatures increasing from 60 to $105^{\circ} \mathrm{C}$, in comparison with other press cakes. Pastuszewska et al. (1998) showed that protein solubility in rapeseed meals decreased due to toasting. Buraczewska et al. (1998) found that with increasing time of toasting, the level of NDF and NDIN in rapeseed meals increased, and that apparent ileal amino acid digestibility was negatively affected in pigs. Newkirk and Classen (2002) reported that due to toasting, the share of NDIN in canola meal protein increased from 11 to $20 \%$, while a dose-response study on broilers fed a non-toasted meal resulted in better performance than on toasted meal. This effect was only seen, however, at above $80 \%$ replacement of soyabean meal protein by canola protein.

In the present study, the high proportion of NDIN in RC 1 resulted in significantly lower protein digestibility, organic matter retention and energy value in comparison with the other RC in the balance trial. This was seen when RC protein made up about $50 \%$ of total dietary protein, while it had no effect on performance in the growth trial, as only $13-17$ and $23-32 \%$ soyabean meal protein was substituted by RC protein in the starter and grower/finisher diets.

Protein solubility indexes in RC 4 were lower than in RC 2 and RC 3 but higher than in RC 1, NDIN and protein digestibility were not negatively affected, while lysine availability and protein digestibility were the highest of all compared cakes. It seems that a very short time of heating and limited content of moisture during dry extrusion prevented protein damage in RC 4, while the destruction of cell wall structures made the protein more available to the digestive enzymes. The reduction of glucosinolate content was, however, smaller in this cake than in the other RCs.

In the present study, the dietary glucosinolate level had no effect on feed intake in the growth trial, although the level of total glucosinolates was from 1.2 to 1.7 $\mathrm{mmol} / \mathrm{kg}$ in the starter diets and from 1.8 to $2.5 \mathrm{mmol}$ per $\mathrm{kg}$ in the grower/finisher diets, respectively. In the digestibility trial chickens voluntarily ate the entire daily portions containing from 4.8 to $6.8 \mathrm{mmol}$ of total glucosinolates per $\mathrm{kg}$. Newkirk and Classen (2002) reported that feed intake was not affected up to the level of $4.5 \mathrm{mmol}$ of total glucosinolates per $\mathrm{kg}$ of diet, while toasting canola meal, which 
lowered the glucosinolate content by $55 \%$, even depressed feed intake in the first weeks of the broilers' life. It seems that the bitter taste of glucosinolates and their volatile bitter degradation products are not noticed by broilers when the feed is provided in the form of pellets. Pigs have more sensitive taste receptors than poultry, but Schöne et al. (1997) reported that up to $6 \mathrm{mmol}$ of glucosinolates per $\mathrm{kg}$ diet did not affect feed intake in pigs.

The glucosinolate content in broiler and fattener pig diets should still be limited, as glucosinolate degradation products, such as vinyl-oxazolidinethiones, nitriles and thiocyanate ions, may have adverse effects on the physiological status of the thyroid, liver and kidneys and on growth performance (Bell, 1993). Glucosinolates are degraded by the enzyme myrosinase, present in rape seeds. Myrosinase and glucosinolates in intact rape seeds are located in separated cellular compartments (Maheshwari et al., 1981), and the crushing of the seed brings them into contact, so inactivation of myrosinase by heat treatment prior to processing is commonly applied (Bell, 1993). However, it was established that glucosinolates may also be hydrolysed in the digestive tract of animals by bacterial enzymes which possess myrosinase-like activity (Campbell et al., 1987; Nugon-Baudon et al., 1990; Słominski et al., 1988).

Thyroid weight was shown to be a sensitive indicator of dietary glucosinolate level and myrosinase status in pigs and chickens, and supplementation of the diets with iodine (I) prevented thyroid weight increase (Schöne et al., 1991, 1997). In the present study all diets contained $1 \mathrm{mg}$ supplementary $1 / \mathrm{kg}$, however, thyroids were normal in the group fed toasted RC 1, while they were enlarged in chickens fed untoasted RC, most significantly in group RC 2 . This indicates that the inactivation of seed myrosinase prior to expelling was inefficient.

In comparison with the control group, the tibia weight, tibia ash and tibia ultimate strength in chickens fed RC-containing diets did not differ. The performance of the chickens fed diets with lowered $\mathrm{Ca}$ and $\mathrm{P}$ contents and supplemented with phytase was similar to the unsupplemented groups. This indicates that exogenous phytase supplementation enabled lowering the dietary inorganic phosphate level, which is in agreement with the results obtained with soyabean meal and maizebased diets supplemented with phytase (Schöner et al.,

1993; Żyła et al., 1999). Rutherfurd et al. (2002) reported that amino acid digestibility in different feedstuffs also increased in broilers in the presence of exogenous phytase. In the present study, however, despite the equal protein, amino acid and fat contents in diets, FCR in groups fed unsupplemented and phytasesupplemented RC diets decreased in comparison with the control group.

It was surprising that supplementation of the diets with phytase induced the enlargement of thyroids, except in birds fed properly toasted RC 1 . The enlargement of thyroids in the chickens from groups fed untoasted, phytase- 
supplemented RC indicates that the exogenous phytase increases hydrolysis of glucosinolates to goitrogenic compounds. This may be due to the enhancement of bacterial activity stimulated by the input of nutrients released by phytase from various complexes in the lower parts of the intestinal tract. The important role of gut microflora in glucosinolate metabolism was demonstrated by Campbell et al. (1995) who found that dietary glucosinolates were excreted intact in germfree rats, while the majority of these compounds disappeared from the digestive tract in animals with normal microflora. In these rats, enlarged thyroids, liver and kidneys were observed, indicating toxicity of glucosinolate derivatives. Also in poultry, the recovery of glucosinolates in excreta was very low in intact hens, but increased greatly in caecectomised or antibiotic-fed hens (Campbell et al., 1987). In the present growth trial, apart from the last week of life, the diets contained an antibiotic growth promoter and a coccidiostatic, which prevent microflora overgrowth to some extent. It may be expected that the effects of phytase on the activation of goitrogenic compounds from cold pressed RC may be even more important when antibiotic-free diets will be fed. The presented results point to the need of further studies on the interactions among of RC production technology, phytase supplementation, and the use of different pre- and probiotic components instead of antibiotics.

The balance trial in the presented study was not aimed to measure phosphorus retention properly (rapeseed cake was not the sole source of phosphorus), and the obtained results have only a limited value. Total phosphorus retention calculated in the balance trial was from $23 \%$ in RC 1 and RC 2, and $27 \%$ in RC 3 and RC 4 , on average, and was not increased due to phytase supplementation. In experiments with rapeseed meal or cake as the sole source of dietary phosphorus, total $\mathrm{P}$ retention from unsupplemented and phytase-supplemented diets was higher: 39 vs $46 \%$ (excreta collection, Leske and Coon, 1999), 37 vs 44\% (ileal digesta collection, Rutherfurd et al., 2002), or 31 vs $44 \%$ (excreta collection; Potkański et al., 1995), but in all the experiments the effect of phytase was not statistically significant. In the growth trial, the tibia ash content in broilers fed RC diets supplemented with phytase was slightly reduced in comparison with respective unsupplemented groups, but tibia weight or its ultimate strength were not affected. It seems that reduction of dietary inorganic $\mathrm{Ca}$ and $\mathrm{P}$ by $18 \%$ in $\mathrm{RC}$-containing broiler diets supplemented with phytase may have no negative consequences for broiler performance.

\section{CONCLUSIONS}

It is concluded that cold-pressed rapeseed cakes can be used in broiler diets. Phytase supplementation may beneficially influence the nutritional value of 
toasted cakes, but it may also negatively affect the thyroid status of birds fed coldpressed rapeseed cakes.

\section{REFERENCES}

AOAC, 1990. Official Methods of Analysis, Association of Official Analytical Chemists. 15th Edition. Washington, DC

Bell J.M., 1993. Factors affecting the nutritional value of canola meal: a review. Can J. Anim. Sci. 73, 679-697

Booth V.H., 1971. Problems in the determination of FDNB-available lysine. J. Sci. Food Agr. 22, 658-666

Buraczewska L., Buraczewski S., 1984. A note on determination of methionine and tryptophan. Proceedings 6th International Symposium on Amino Acids, Serock (Poland), pp. 47-50

Buraczewska L., Gdala J., Wasilewko J., Buraczewski S., 1998. Ileal digestibility in pigs of protein and amino acids of heat treated rapeseed feeds as affected by protein associated with the NDF fraction (in Polish). Rośliny Oleiste 19, 175-186

Campbell L.D., Słominski B.A., Nugon-Baudon L., Rabot S., Lory S., Quinsac A., Krouti M., Ribaillier D., 1995. Studies on intestinal tract glucosinolate content, xenobiotic metabolizing enzymes and thyroid status in germ-free and conventional rats fed rapeseed meal. Proceedings of 9th International Rapeseed Congress, Cambridge (UK), Vol. 1, 209-211

Campbell L.D., Słominski B.A., Stanger N.E., 1987. Influence of cecectomy and dietary antibiotics on the fate of ingested intact glucosinolates in poultry. Proceedings of 7 th International Rapeseed Congress, Poznań (Poland), Vol. 7, 1704-1709

Dudley-Cash W.A.,1999. Methods for determining quality of soybean meal protein important. Feedstuffs 71 (1), 10-11

Ekman P., Emanuelson H., Fransson A., 1949. The digestibility of protein in poultry. KGL Lantbruks.Hogskol. Ann. 16, 749

Hill F.W., Anderson D.L., 1958. Comparison of metabolizable energy and productive energy determinations with growing chicks. J. Nutr. 64, 587-603

Hinsberg K., Cremer H.D., Schmid G., 1953. In: Hoppe-Seyler/Thierfelder-Handbuch der Physiologisch-und Patologisch-Chemischen Analyse. Springer-Verlag, Berlin, pp. 402-403

International Organization for Standardization, 1992. 9167-1. Rapeseeds - Determination of glucosinolates content. Part 1. Method using gradient elution high performance liquid chromatography. ISO, Geneva

Krzymański J., 1993. Possibility to take the full advantages of the quality of double-low oilseed rape (in Polish). Post. Nauk rol. (6), 161-166

Lee H., Garlich J.D., 1992. Effect of overcooked soybean meal on chicken performance and amino acid availability. Poultry Sci. 71, 499-508

Leske K.L., Coon C.N., 1999. A bioassay to determine the effect of phytase on phytate phosphorus hydrolysis and total phosphorus retention of feed ingredients as determined with broilers and laying hens. Poultry Sci. 78, 1151-1157

Maheshwari P.N., Stanley D.W., Beveridge T.J., Van de Voort F.R., 1981. Localization of myrosinase (thioglucoside glucohydrolase, EC.3.2.3.1) in cotyledon cells of rapeseed. J. Food Bioch. 5, 3961

Newkirk R.W., Classen H.L., 1998. In vitro hydrolysis of phytate in canola meal with purified and crude sources of phytase. Anim. Feed Sci. Tech. 72, 315-327

Newkirk R.W., Classen H.L., 2002. The effects of toasting canola meal on body weight, feed conversion efficiency, and mortality in broiler chickens. Poultry Sci. 81, 815-825 
Nugon-Baudon L., Rabot S., Wal J.M., Szylit O., 1990. Interaction of the intestinal microflora with glucosinolates in rapeseed meal toxicity: first evidence of an intestinal Lactobacillus possessing a myrosinase-like activity in vivo. J. Sci. Food Agr. 52, 547-559

Pastuszewska B., Buraczewska L., Ochtabińska A., Buraczewski S., 1998. Protein solubility as an indicator of overheating rapeseed oilmeal and cake. J. Anim. Feed Sci. 7, 73-82

Potkański A., Dänicke S., Rutkowski A., Jeroch H., Kracht W., 1995. Availability of phosphorous of rapeseed meal and rapeseed meal expeller for growing chickens and improvement of phosphorus availability by graded enzyme addition. Proceedings of 9th International Rapeseed Congress, Cambridge (UK), Vol. 1, 157-160

Rutherfurd S.M., Chung T.K., Moughan P.J., 2002. The effect of microbial phytase on ileal phosphorus and amino acid digestibility in the broiler chicken. Brit. Poultry Sci. 43, 598-606

Rutherfurd S.M., Chung T.K., Moughan P.J., 2004. The effect of commercial microbial phytase preparation on the in vitro release of phosphorus and amino acids from selected plant feedstuffs supplemented with free amino acids. J. Anim. Feed Sci. 13, 677-690

SAS, 1994-2001. Statgraphics ${ }^{\circledR}$ ver. 5.1. Statistical Graphic System by Statistical Graphic Corporation (USA)

Schöner F.J., Hoppe P.P., Schwarz G., Wiesche H., 1993. Comparison of microbial phytase and inorganic phosphate in male chickens - the influence on performance data, mineral retention and dietary calcium. J. Anim. Physiol. Anim. Nutr. 69, 235-244

Schöne F., Hennig A., Groppel B., Lange R., 1991. Evaluation of low and high glucosinolate rapeseed meals in experiments with growing pigs and poultry. Proceedings of 8th International Rapeseed Congress, Saskatoon (Canada), pp. 382-389

Schöne F., Rudolph B., Kirchheim U., Knapp G., 1997. Counteracting the negative effects of rapeseed and rapeseed press cake in pig diets. Brit. J. Nutr. 78, 947-962

Słominski B.A., Campbell L.D., Stanger N.E., 1988. Extent of hydrolysis in the intestinal tract and potential absorption of intact glucosinolates in laying hens. J. Sci. Food Agr. 42, 305-314

Smulikowska S., Pastuszewska B., Mieczkowska A., Ochtabińska A., 1997. Chemical composition, energy value for chickens, and protein utilization in rats of rapeseed expeller cakes produced by different pressing technologies. J. Anim. Feed Sci. 6, 109-121

Tangkongchitr V., Seib P.A., Hoseney R.C., 1981. Phytic acid. I. Determination of three forms of phosphorus in flour, dough and bread. Cereal Chem. 58, 226-228

Van Soest P.J., 1973. Collaborative study of acid detergent fiber and lignin. J. Assn. Off. Agr. Chem. 56, 513-530

Van Soest P.J., Wine R.H., 1967. Use of detergents in the analysis of fibrous feeds. IV. Determination of plant cell constituents. J. Assn. Off. Agr. Chem. 50, 50-55

Żyła K., Gogol D., Koreleski J., Świątkiewicz S., Ledoux D.R., 1999. Simultaneous application of phytase and xylanase to broiler feeds based on wheat: feeding experiment with growing broilers. J. Sci. Food Agr. 79, 1841-1848

Żyła K., Koreleski J., 1993. In vitro and in vivo dephosphorylation of rapeseed meal by means of phytate-degrading enzymes derived from Aspergillus niger. J. Sci. Food Agr. 61, 1-6 